\title{
ЗАСТОСУВАННЯ МАСАЖНОЇ КРІОПРОЦЕДУРИ ПРИ БОЛЬОВОМУ СИНДРОМІ ОПОРНО-РУХОВОГО АПАРАТУ
}

Застосування масажної кріопроцедури при больовому синдромі опорно-рухового апарату

\section{А. А. Опарін ${ }^{1}$, Т. Н. Опаріна², В. В. Буткевич ${ }^{2}$}

Харківська медична академія післядипломної освіти ${ }^{1}$ Український гуманітарний інститут

Резюме. У статmі представлено проблематику поширення больового синдрому серед населення та подолання болю медикаментами; подано коротку історичну довідку та проаналізовано наукові публікації щодо застосування кріопроцедур при лікуванні різних захворювань, у тому числі больового синдрому опорно-рухового апарату. Проведено огляд видів больового синдрому, розглянуто механізм фрізіологічного впливу локальної кріотерапії на біль у м'язах, фрасціях та суглобах. Обґрунтовано доведено позитивну дію кріотерапії при хронічному болю, що супроводжуються застійними явищами у тканинах, порушенням мікроциркуляції крові й лімфи та запальним процесом.

Мета дослідження - об'рунтувати ефективність дії кріомасажу на пацієнтів із больовим синдромом опорно-рухового апарату.

Матеріали і методи. Описано різноманітні сучасні методи кріовпливу, а також особливості методу кріомасажу льодом, перелік застережень щодо його застосування. Вважають, що альтернативним методом подолання больового синдрому є кріомасаж, який не має побічних негативних наслідків та не потребує особливих зусиль.

Результати. 3'ясовано, що холод надає потужний подразнювальний ефект на чентральну нервову систему, пригнічує біль та пришвидшує кровотік. Виявлено, що під час кріомасажу відбувається швидке відновлення тканин та їх функціональності, дана техніка $є$ простою у виконанні, не потребує особливих витрат, може проводитися у домашніх умовах та в якості звичайного масажу. Автори статті зазначили, що протипоказання до кріомасажу носять загальний характер та не відрізняються від тих, що зазначені для класичного. Важливим фрактором є те, що потенціал кріопроцедур обмежений адаптивними можливостями людини, тому реакції можуть бути різними. Незважаючи на деякі недоліки, застосування кріомасажу є надзвичайно ефективним та у більшості випадках дає хороший результат. У процесі дослідження було виявлено, що ключовою перевагою кріомасажу є відсутність по-

(๑). А. Опарін та ін., 2021
Application of massage cryoprocedure with pain syndrome of the musculoskeletal system

A. A. Oparin ${ }^{1}$, T. N. Oparina ${ }^{2}$, V. V. Butkevych ${ }^{2}$

Kharkiv Medical Academy of Postgraduate Education ${ }^{1}$ Ukrainian Institute of Arts and Sciences ${ }^{2}$

e-mail: oparinaa@ukr.net

Summary. The article presents the problem of the spread of pain among the population and overcoming pain with medication; a brief historical background is presented and scientific publications on the use of cryotherapy in the treatment of various diseases, including musculoskeletal pain, are analyzed. An overview of the types of pain syndrome, the mechanism of physiological effects of local cryotherapy in pain in muscles, fascia and joints. The positive effect of cryotherapy for chronic pain, accompanied by stagnation in the tissues, impaired microcirculation of blood and lymph and inflammation is substantiated.

The aim of the study - to substantiate the effectiveness of cryomassage on patients with musculoskeletal pain.

Materials and Methods. Various modern methods of cryotherapy are described, as well as features of the method of ice cryomassage, a list of caveats for its use. The author of the study concludes that an alternative method of overcoming the pain syndrome is cryomassage, which has no negative side effects and does not require much effort.

Results. Cold has been shown to have a powerful irritating effect on the central nervous system, suppressing pain and speeding up blood flow. It has been found that during cryomassage there is a rapid recovery of tissues and their functionality, this technique is easy to perform, does not require special costs, can be performed at home and as a regular massage. The author of the article have found that the contraindications to cryomassages are general in nature and do not differ from those listed for the classic. An important factor is that the potential of cryotherapy is limited by the adaptive capacity of man, so the reactions may be different. The author note that despite some shortcomings, the use of cryomassage is extremely effective and in most cases gives good results. The study found that the key advantage of cryomassage is the lack has of side effects and addiction observed in medication.

Conclusions. Cryomassage is one of the alternative methods of overcoming the pain syndrome and its causes. Unlike medications, cryotherapy has no side effects. Cold
ISSN 2706-6282(print) ISSN 2706-6290(online)
Вісник медичних і біологічних досліджень Bulletin of Medical and Biological Research 
бічних ефректів та звикання, що спостерігається при лікуванні медикаментами.

Висновки. Одним 3 альтернативних методів подолання больового синдрому та його причин $є$ кріомасаж. На відміну від медикаментів кріопроцедури не мають побічних негативних наслідків. Холод здійснює багатосторонній потужний подразнювальний вплив на центральну нервову систему, який викликає низку позитивних зрушень в ендокринній, імунній, кровоносній, лімфатичній та інших системах організму, знеболює, призупиняє запальний процес.

Ключові слова: масаж; кріопроцедури; больовий синдром опорно-руховий апарат; медикаменти.

\section{ВСТУП}

Больовий синдром різної локалізації - масштабна проблема сучасності. Саме відчуття болю - основна причина звернень пацієнтів до лікаря (за даними світової статистики їх чисельність сягає $90 \%)$. При цьому больовий синдром опорно-рухового апарату впевнено посідає друге місце за частотою скарг після головного болю. В Європі 74,5 \% людей віком від 25 років відзначали один із різновидів м'язово-суглобного болю упродовж останнього року $[12,10]$. Сучасні методи вирішення питання болю та запальних процесів при захворюваннях м'язово-зв'язкового апарату часто мають негативні наслідки від побічних дій медикаментів. Знеболювальні фрармацевтичні засоби викликають ураження інших систем організму, а також синдром звикання пацієнта до препарату, через що виникає потреба у збільшенні дози діючої речовини. Таким чином, проблема патології, через яку виник біль, не вирішується, та й сам біль перетворюється у хронічний і прогресуючий. Медикаментозне лікування є переважно симптоматичним, направленим не стільки на причину, скільки на наслідки хвороби. У пошуках альтернативних методів позбавлення болю, які би не мали руйнівної дії на людський організм, науковці все частіше звертають увагу на природні засоби вирішення зазначеної проблеми. Одним із таких засобів є кріотерапія - лікування холодом.

Метою дослідження було обґрунтувати ефективність дії кріомасажу на пацієнтів із больовим синдромом опорно-рухового апарату.

\section{МАТЕРІАЛИ I МЕТОДИ}

Описано різноманітні сучасні методи кріовпливу, а також особливості методу кріомасажу льодом, перелік застережень щодо його застосування. Вважають, що альтернативним методом подолання больового синдрому $є$ кріомасаж, який не має побічних негативних наслідків та не потребує особливих зусиль. has a powerful multifaceted irritant effect on the central nervous system, which causes a number of positive changes in the endocrine, immune, circulatory, lymphatic and other systems of the body, relieves pain, suspends the inflammatory process.

Key words: massage; cryotherapy; musculoskeletal pain; medications.

\section{РЕЗУЛЬТАТИ Й ОБГОВОРЕННЯ}

Згадки про використання природного холоду у вигляді льоду для знеболювання та зняття набряків знаходили ще у давніх папірусах. Кріопроцедури описали Гіппократ, Авіцена, Цельсій, Гален як результативний метод зменшення болю, запального процесу та м'язового спазму. Кріотерапія описана в працях М. І. Пирогова та інших відомих лікарів сучасності [1]. В офріційну медицину поняття «кріотерапія» ввів католицький німецький священик Себастьян Кнейп (1821-1897). Він систематизував водолікування, яке застосовували жреці давнього Єгипту, Греції, Риму та Індії, в методику тренування та загартування організму, винайшов водні компреси [2].

Кінець XX ст. характеризується розробкою нових видів кріоносіїв, вивченням впливу холоду на різні системи організму та розкриттям механізмів адаптації людини до їх дії. Відповідно до досліджень короткострокова дія холоду активує усі ресурси організму, які відповідають за адаптацію. Одночасно працюють імунна, ендокринна, терморегуляційна та нейрогуморальна системи [3]. Кріотерапевтичні методики мають велике значення для практичної медицини, адже забезпечують немедикаментозне лікування низки тяжких захворювань. Завдяки високій лікувальній ефективності холодові процедури отримали в країнах Заходу широке визнання, а в Німеччині та Польщі увійшли в перелік фрізіотерапевтичних методів, що фрінансуються за рахунок державного медичного страхування [4]. Автори описують порядок проведення кріосеансів і результати вимірів окремих характеристик стану пацієнта до та після процедури [5].

У медичній літературі до кріотерапії відносять аплікації частинками прісного та солоного льоду (-12-18 $\left.{ }^{\circ} \mathrm{C}\right)$, спеціальними низькотемпературними гелями $\left(-12{ }^{\circ} \mathrm{C}\right)$, лікувальною гряззю $\left(-3-4{ }^{\circ} \mathrm{C}\right)$; низькотемпературні компреси 3 використанням силіконових акумуляторів холоду [6]. Кріотерапевтичними процедурами називають лише ті методики, які забезпечують отримання так званого кріотера- 
певтичного ефекту - багатопланового позитивного впливу на організм пацієнта з акцентом на тривалу анальгетичну дію, тобто немедикаментозного неспецифрічного пригнічення больового відчуття [7].

Автор методу загальної кріотерапії Т. Ямаучі дослідив анальгетичний ефект кріопроцедур тривалістю 6 год, який став основою запропонованої ним методики лікування больового синдрому в пацієнтів із ревматоїдним поліартритом [8]. Клінічна практика ревматолога з Німеччини Р. Фріке підтвердила ефективність методу Т. Ямаучі [9]. Згадки у наукових роботах про масажну техніку з використанням льоду при больовому синдромі м'язово-зв'язкового апарату досить обмежені та недостатні.

Больовий синдром може бути гострим або хронічним. Гострий біль має сигнальну роль. Зазвичай він $€$ наслідком запального процесу, травми, триває обмежений час та відрізняється інтенсивністю. Якщо біль виходить за очікувані межі періоду одужання, його прийнято вважати хронічним. Сигнальна роль такого болю перетворюється у руйнівний фрактор, викликаючи довготривале страждання, порушення систем регуляції, психоневрологічні та імунні розлади. Серед інших видів хронічного болю виділяють м'язово-скелетний біль - біль, що виникає під впливом больових рецепторів. Сюди відносять суглобовий (у т. ч. фрасеточний - коли це стосується хребта), міофасціальний та м'язовотонічний больові синдроми.

М'язовотонічний больовий синдром розвивається в результаті провокуючого фрактора, який спричиняє активацію ноцицепторів (фізичне перенавантаження, гіподинамія або тривала фріксована поза, порушення постави, стрес, різкий рух, переохолодження, дегенеративно-дистрофічні процеси хребта, зв'язок, м'язів тощо). Ноцицептивна імпульсація викликає м'язове рефрлекторне скорочення та больовий спазм. Формується порочне коло «біль м'язовий спазм - біль...», процес хронізується і важко піддається лікуванню. Прояви м'язовотонічного больового синдрому: напруження та ущільнення м'язів, обмеження обсягу руху в результаті спазмування, можлива поява відчуття оніміння, холоду або жару в кінцівках, локальні парестезії.

Фасеточний больовий синдром зумовлений спондилоартрозом хребта. Частою його причиною $€$ дегенеративно-дистрофічний процес міжхребцевого диска, що призводить до підвивиху та мікропереломів хребців. Патологію суглобів спричиняють також гострі інфекційні захворювання, ревматоїдний артрит, метаболічні розлади (подагра). Прояви орасеточного больового синдрому: обмежений рух, локальний паравертебральний біль у зоні патологічного суглоба. Біль посилюється після сну та ближче до кінця дня, а також при обертах та розгинальних рухах.

Ще одним різновидом $є$ міофасціальний больовий синдром. Термін «міофрасціальний» складений 3 двох частин: «міо» - м'яз і «фрасція» - м'язова оболонка. Причиною спазму м'язового волокна може бути дегенерація фрасції: оболонка стискається, зменшується, ущільняється і ніби затискає в собі м'яз, який згодом атрофується, щоб «комфрортно» почувати себе в зменшеній фасції. Таким чином, порушуються обмінні й вегетативні процеси, м'язова тканина може перероджуватися у сполучну або жирову. Провокуючі фрактори подібні до тих, що при м'язовотонічному синдромі. Біль зароджується внаслідок регулярних мікроспазмів тих чи інших волокон. Згодом в місці регулярного спазму формується тригерна точка, що пальпується під час огляду як больовий тяж - хвороблива ущільнена м'язова ділянка, при натисканні на яку спостерігається посилення болю. Для міофасціального синдрому характерний гострий біль, який зазвичай локалізується в спині та іррадіює в сторону суглобів.

Отже, основними проблемами больового синдрому опорно-рухового апарату є: орормування так званого «замкненого кола» біль-спазм-біль; порушення мікроциркуляції, обмінних процесів, застійні явища у тканинах; запальний процес. Для подолання зазначених явищ використовують різні немедикаментозні методи орізіотерапії, лікувальної фрізкультури, масажу. Серед ефрективних фрізіотерапевтичних засобів рекомендується і кріолікування.

Розглянемо детальніше фрізіологічний вплив кріотерапії при больовому синдромі. Слово «кріотерапія» походить від грецьких слів «kryos» - холод та «therapуа» - лікування, тобто лікування холодом. Розрізняють локальну та загальну кріотерапію. Під час локальної кріотерапії використовують тверді, рідкі або газоподібні холодоагенти для відведення тепла від окремих ділянок тіла у такій мірі, щоби температура тканин знижувалася у межах її кріостійкості й не відбувалося значних порушень терморегуляції організму.

Початкова захисна реакція на охолодження - звуження мікрокапілярів та артеріол шкіри, уповільнення кровотоку. Наступна захисна реакція - розширення судин, що сприяє посиленому теплоутворенню та зниженню м'язового тонусу. Відбувається розширення не тільки діючих а й резервних капілярів, що значно посилює приплив крові та обмін речовин у місці аплікації. Це проявляється активною артеріальною гіперемією і може продовжуватися 1-3 год. Ця фраза є компенсаторною, перешкоджає ішемії та порушенню живлення тканин. Розвивається покращення венозного та лімфатичного відтоку. Охолодження сприяє блокуванню больових рецепторів: почуття холоду, печіння, поколювання та болю змінюється анестезією та анальгезією.

У підсумку, при локальній кріотерапії спостерігаються такі основні ефекти: протизапальний ефект - забезпечується дегідратацією тканин, зниженням активності медіаторів запалення, збільшенням
ISSN 2706-6282(print)

ISSN 2706-6290(online)
Вісник медичних і біологічних досліджень

Bulletin of Medical and Biological Research
3(9),2021 
протизапальних та зменшенням прозапальних цитокинів. Локальне охолодження знімає набряк, стаз, нормалізує лімфотік, послаблює алергічний компонент; анальгетичний ефект - відбувається від різкого зниження провідності нервової тканини, активізації ендорорінних систем, нейтралізації хімічних реакцій за участю ацетилхоліну, гістаміну, простагландинів, що призводить до вираженої анальгезії (стану пригніченості больової чутливості), локальної анестезії та розриву замкненого кола «більм'язовий спазм-біль»; регуляція м'язового тонусу - внаслідок гальмування фрункцій мотонейронної системи відбувається фрізіологічна міорелаксація, знімається м'язовий спазм, контрактура. Короткотривале охолодження сприяє покращенню тургору шкіри, збільшенню витривалості м'язів; активація метаболізму - внаслідок посилення вуглеводного обміну; ритмічна зміна звуження та розширення судин призводить до відкриття артеріовенозних анастомозів (додаткових сполучень між судинами), що призводить до покращення циркуляції кров'яного та лімфратичного русла, активації клітинного та гуморального імунітету за рахунок нормалізації показників Т-лімфроцитів.

Таким чином, застосування локальної кріотерапії при лікуванні больового синдрому опорно-рухового апарату $є$ ефрективним та доцільним, адже сприяє вирішенню основних проблем даної патології. Однак існують деякі застереження стосовно протипоказань до проведення лікування холодом. Кріопроцедури протипоказані при непереносимості холоду, холодовій алергії, порушеннях периферичного артеріального кровообігу, серпоподібноклітинній анемії; i обмежено показані - хворим із діабетичним ураженням судин. Варто дотримуватися обережності при використанні методу на маленьких дітях та людях похилого віку у зв'язку із особливостями терморегуляції. Не варто використовувати кріотерапію у разі наявності в тканинах імплантатів, що змінюють свої властивості під впливом зниження температури.

Проведемо огляд кріопроцедур та окреслимо сореру їх застосування. Велике різноманіття кріометодів у лікуванні хвороб дозволяє обирати оптимальний засіб у будь-якому конкретному випадку. При больовому синдромі опорно-рухового апарату використовують льодові та холодні грязеві компреси, кріоаплікації за допомогою термоелектричних пристроїв, безконтактну локальну аерокріотерапію, хлоретилові та спиртові блокади, масаж кубиками льоду, розтирання рідким азотом, $\mathrm{CO}_{2}$-аерозолем (у тому числі обробку тригерних больових точок).

У медичній літературі описується позитивний досвід застосування локальної повітряної кріотерапії в комплексному лікуванні дегенеративних змін хребта у зв'язку із анальгезуючим, спазмолітичним та протизапальним ефектом. Після впливу охолоджуючого повітряного струменя $\left(-30^{\circ} \mathrm{C}\right)$ на больові сегменти хребта тривалістю 5 хв при курсовому лікуванні відзначалося зменшення больового синдрому, значне зниження напруги при виконанні фрізичних вправ та збільшення об'єму рухів [2].

Для отримання кращого лікувального ефекту кріотерапію комбінують 3 іншими фрізіотерапевтичними засобами: магнітотерапією, дарсонвалізацією, електрофрорезом тощо. Доктор медичних наук С. М. Бубновський розробив та успішно застосував методику кріотерапії при остеохондрозі шийного відділу хребта із м'язово-тонічним синдромом плечового пояса, яку поєднують із руховим режимом пацієнта. При цьому на тлі локального охолодження вогнища болю за допомогою манжети з кріорозчином виконуються вправи на тренажерах, направлені на збільшення амплітуди руху в плечовому суглобі та покращення місцевого кровообігу [11].

Аналіз досвіду та практики науковців дозволяє зробити висновок, що кріотерапевтичні процедури мають пролонговану та посилену дію у поєднанні 3 іншими засобами впливу на органи, уражені больовим синдромом. Одним із таких засобів є лікувальний масаж: класичний, точковий, мануальний, міофасціальний, сегментарний, лімфодренажний тощо. Крім того, сама кріопроцедура може виконуватися як кріомасаж, тобто із застосуванням масажних прийомів (погладжування, розтирання, натискання і т. п.). Найбільш доступними та мало витратними для лікування больового синдрому опорно-рухового апарату в умовах масажного кабінету виявилися локальні методи кріотерапії із застосуванням помірно низьких температур, таких як масаж кубиками льоду.

Охарактеризуємо масаж льодом при больовому синдромі та особливості його реалізації. Масаж кубиками льоду - метод кріотерапії, який поєднує місцевий вплив холоду на уражені больовим синдромом тканини в комплексі з масажними прийомами. Процедура може проводитися як у домашніх умовах, так і на прийомі у масажиста, не потребує спеціальної апаратури, додаткової професійної підготовки, адже даний вид кріомасажу виконується за принципами звичайного масажу з використанням знань щодо показань та протипоказань, основних масажних прийомів. Необхідні засоби для проведення кріомасажу льодом: бавовняне простирадло, на якому лежить пацієнт, махровий рушник для вбирання талої води при плавленні льоду, додатковий рушник для обтирання, кубик льоду (3х3 см), невеличка бавовняна серветка або рукавичка, годинник. Замість чистої води для отримання льоду можна використовувати настої лікарських трав, сік чорної редьки, сік хрону, додавати ароматичні олії, декілька крапель настоянки перця стручкового, ментолу тощо.

Розглянемо послідовність виконання масажу льодом на прикладі його комбінації із класичним масажем спини. У даному випадку масаж виконують 
без використання речовин для змащування - насухо. Вступна або підготовча частина масажу не передбачає застосування льоду, її проводять звичайним способом із метою загального розслаблення пацієнта та розігріву тіла. Сюди входять такі маніпуляції, як погладжування, розтирання, вижимання, розминання усієї поверхні спини. В основній частині масажист працює сегментарно, розминаючи м'язи пацієнта та вивчаючи їх стан, відмічаючи для себе особливі больові ділянки - активні тригерні точки, м'язи з підвищеним тонусом, місцевим набряком, видозмінені ущільнені тканини тощо.

Закінчуючи основну частину масажу, потрібно визначитись 3 місцем проведення наступного його етапу - безпосередньо кріопроцедури з льодом. Пріоритет віддається найпроблемнішому місцю, яке є джерелом найбільшого дискомфорту для хворого на даний момент. Якщо, наприклад, поруч знаходиться декілька тригерних точок, їх можна об'єднати в одну робочу зону. Площа робочої зони не має перевищувати 100-200 см² (наприклад квадрат 10х10 см). Вибране місце обкладається по колу махровим рушником, який буде вбирати талу воду. Масажист бере в робочу руку кубик льоду, попередньо одягнувши захисну рукавичку або обгорнувши кубик з одного боку серветкою. Далі проводяться масажні рухи кубиком льоду в зоні проблемного місця або тригерної точки. Спостереження показують, що більш прийнятними масажними рухами із застосуванням льоду є інтенсивні погладжування та вижимання. Кубик льоду має постійно контактувати з тілом.

Кубик розміром 3×3 см розтане приблизно через 4-5 хв. Цей термін і є середнім оптимальним для отримання кріоефекту: спочатку пацієнт відчує в місці маніпуляції холод, печіння, поколювання, потім біль зміниться анестезією та анальгезією, а в місці проведення процедури з'явиться значна гіперемія. Масаж льодом повинен бути суворо дозованим - 4-5 хв на одній ділянці. Або - до досягнення вираженої гіперемії, але не більше 10 хв. Ступінь прояву лікувальної дії кріотерапії залежить від таких параметрів: тривалості, інтенсивності маніпуляцій, площі поверхні, яка обробляється, характеру патології, індивідуальних особливостей та віку пацієнта. Розповсюдження холоду на шкірі залежить від товщини епідермісу, жирової основи шкіри, м'язів, складу води у тканинах та швидкості кровотоку.

Щоби попередити травмування та переохолодження тканин, потрібно дотримуватися правил, не застосовувати холод без попереднього розігріву тіла, а також на ділянках із ушкодженою шкірою, або надто ніжною, тонкою, з поганою перфузією (повільним надходженням крові до тканини). Після досягнення кріоефекту потрібно другим рушником витерти насухо шкіру пацієнта і розім'яти м'язи не тільки у місці проведення масажу льодом, а і по всій поверхні спини, окремо зосередитись на больових точках, закінчити масаж звичайним способом.

Пацієнт має відчути релаксацію, знеболювання, жар у місці льодового масажу. Таким чином досягається такий результат: у хворому місці покращується метаболізм, що зменшує явища застою в тканинах, вони інтенсивно живляться, отримуючи поживні речовини для відновлення, і, разом з тим позбавляються продуктів розпаду через покращення лімфродренажу, знімається набряк, запалення, відбувається швидка регенерація. Завдяки анальгезуючому ефекту руйнується замкнена схема біль-спазм-біль. Кріомасаж проводять курсом у 5-7 процедур, включивши його в середину курсу 10-14 процедур звичайного масажу. Еорект кріомасажу заснований на адаптивних можливостях організму, які є обмеженими та індивідуальними.

\section{ВИСНОВКИ}

Одним 3 альтернативних методів подолання больового синдрому та його причин є кріомасаж. На відміну від медикаментів кріопроцедури не мають побічних негативних наслідків. Холод здійснює багатосторонній потужний подразнювальний вплив на центральну нервову систему, який викликає низку позитивних зрушень в ендокринній, імунній, кровоносній, лімфратичній та інших системах організму, знеболює, призупиняє запальний процес. Відбувається швидке відновлення тканин і їхньої функціональності. Техніка масажу з льодом є простою у виконанні, не потребує матеріальних затрат та часу, може проводитися в домашніх умовах, а також виконуватися у якості самомасажу. Протипоказання до масажу з льодом є загальними 3 протипоказаннями до звичайного класичного лікувального масажу, але відмічені й особливі застереження. Крім того, потенціал дії даної кріопроцедури обмежений адаптивними можливостями людини, тому вона не може бути застосована на постійній основі. Але наведені переваги свідчать про те, що використання кріомасажу є надзвичайно доцільним і потребує детальнішого дослідження на практиці 3 метою впорядкування різноманітності методик кріовпливу і технік їх виконання.
Вісник медичних і біологічних досліджень Bulletin of Medical and Biological Research
$3(9), 2021$ 


\section{СПИСОК ЛІТЕРАТУРИ}

1. Криотерапия : учебно-методическое пособие для врачей / А. В. Волотовская, Г. К. Колтович, Л. Е. Козловская, А. Н. Мумин. - Минск : БЕЛМАПО, 2010. - 26 с.

2. Горбунова Н. И. Криотерапия в лечении больных с дегенеративно-дистросрическими заболеваниями позвоночника / Н. И. Горбунова, Л. М. Тибекина // Вестник Санкт-Петербургского университета. Медицина. - 2018. - № 1. - С. 58-71.

3. Буренина И. А. Современные методики криотерапии в клинической практике / И. А. Буренина // Вестник Санкт-Петербургского университета. Медицина. - 2014. - № 7. - С. 57-61.

4. Баранов А. Ю. Низкотемпературные установки медицинского назначения. Ч. 1. Аппараты для общего криотерапевтического воздействия : учеб. пособие / А. Ю. Баранов. - СПб. : Университет ИТМО, 2016. $178 \mathrm{c}$.

5. Медицинская криология : сб. науч. трудов к 40-летию криодеструкции с использованием жидкого азота и специальных устройств / под ред. В. И. Коченова. Вып. 1, 2, 3, 4. - Н. Новгород, 2001-2003.

6. Костадинов Д. Криотерапия / Д. Костадинов, Т. Краев. - София, 1987. - 98 с.

\section{REFERENCES}

1.Volotovskaya AV, Koltovich GK, Kozlovskaya LE, Mumin AN. Cryotherapy. [Криотерапия] Teaching aid for doctors. Minsk: BELMAPO; 2010. Russian.

2. Gorbunova NI, Tibekina LM. [Cryotherapy in the treatment of patients with degenerative-dystrophic diseases of the spine]. Vestnik Sankt-Peterburgskogo universiteta. Meditsina. 2018;1: 58-71. Russian.

3. Burenina IA. [Modern cryotherapy techniques in clinical practice]. Vestnik Sankt-Peterburgskogo universiteta. Meditsina. 2014;7: 57-61. Russian.

4. Baranov AJu. Low-temperature medical installations Part 1. Apparatus for general cryotherapy. [Низкотемпературные установки медицинского назначения Ч. 1. Аппараты для общего криотерапевтического воздействия] Saint-Petersburg: Universitet ITMO; 2016. Russian.

5. Medical cryology. [Медицинская криология].Sat. scientific. works dedicated to the 40th anniversary of cryodestruction using liquid nitrogen and special devices. Kochenova VI, editor. N.Novgorod; 2001-2003. Vol. 1, 2, 3, 4. Russian

6. Kostadinov D, Kraev T. Cryotherapy. [Криотерапия] Sofiya; 1987. Russian.
7. Малышева Т. А. Выбор и обоснование параметров технологического процесса криотерапевтического воздействия: дис. ... канд. техн. наук : 05.04.03, 01.04.14 / Малышева Татьяна Алексеевна - СПб., 2007. - 154 с.

8. Yamauchi T. Whole body cryo-therapy is method of extreme cold $-175^{\circ} \mathrm{C}$ treatment initially uses for rheumatoid arthrisis / T. Yamauchi // Zeitschrift. Phys. Med. Baln. Med. Klim. - 1986. - No. 15. - P. 311-313.

9. Fricke R. Was leistet die Kältetherapie bei rheumatischen Erkrankungen? / R. Fricke // Rheuma-Journal. 1999. - No. 1. - P. 28-29.

10. Woolf A. D. Musculoskeletal pain: incidence, prevalence and impact on healthy ageing / A. D. Woolf // Chair, Bone and Joint Decade. - 2010-2020.

11. Бобков Г. А. Термопроцедуры и кинезитерапия / Г. А. Бобков // Профилактика и лечение заболеваний костно-мышечной системы человека по методу С. Бубновского. - М. : Материалы научно-практической конореренции. - М., 2008. - С. 116.

12. Мамчур В. І. Питання ефективності та безпеки при наданні допомоги пацієнтові з больовим синдромом / В. І. Мамчур, О. Ю. Коваленко // Здоров'я України. 2016. - № 24. - C. 18-19.

7. Malysheva TA. Selection and justification of the parameters of the technological process of cryotherapeutic exposure. Candidate's thesis. 05.04.03, 01.04.14. SaintPetersburg; 2007. Russian.

8. Yamauchi T. Whole body cryo-therapy is method of extreme cold $-175{ }^{\circ} \mathrm{C}$ treatment initially uses for Rheumatoid Arthrisis. Zeitschrift Phys Med Baln Med Klim. 1986;15: 311-3.

9. Fricke R. Was leistet die Kältetherapie bei rheumatischen Erkrankungen? Rheuma-Journal. 1999;1: 28-9.

10. Woolf AD. Musculoskeletal pain: incidence, prevalence and impact on healthy ageing. Chair, Bone and Joint Decade. 2010-2020.

11. Bobkov GA. Thermal procedures and kinesitherapy. Prevention and treatment of diseases of the human musculoskeletal system according to the method of Bubnovsky S. M. [Профрилактика и лечение заболеваний костно-мышечной системы человека по методу Бубновского С. М.] Proceedings of the scientific and practical conference. Moscow; 2008. Russian.

12. Mamchur VI, Kovalenko OYu. [Nutrition of efficiency and safety when providing additional assistance to patients with pain syndrome]. Zdorovia Ukrainy. 2016;24: 18-9. Ukrainian. 